\title{
The Implementation of School Literacy Movement at the Senior High School
}

\author{
Fahmi Ashari S. Sihaloho', Trisno Martono을 Akhmad Daerobi ${ }^{3}$
}

\section{ARTICLE INFO}

Article History:

Received 23.09.2018

Received in revised form

23.11.2018

Accepted

Available online 01.01.2019

\begin{abstract}
Literacy skill is an individual's ability to access, understand, and organize information that he or she has to be used in various activities in his or her life. By having good literacy skill, a student is expected to maximize the development of critical, creative, and social-empathy skills as well as knowledge affection. Therefore, the School Literacy Movement (GLS) program appears to help expedite the development of the students' literacy skill. However, in its implementation, the GLS program still needs to be refined so that it can be in accordance with the condition in the field. This research uses qualitative research methodology. The purpose of this research is to help schools solve problems in implementing GLS program in the field. By means of this research, it is expected that the implementation of GLS program can run optimally and bring about students with good literacy skill.
\end{abstract}

(C) IJERE. All rights reserved

Keywords: ${ }^{1}$

Students' literacy skill, school literacy movement, senior high school

\section{INTRODUCTION}

The gap between the skills a student learns informally and formally with the skills needed to fill jobs is increasingly apparent. This indicates that the current education has failed in helping students to grow up in accordance with the development of the work field. For this reason, the World Economic Forum (WEF) formulates several skills that need to be developed to meet the demands of the $21^{\text {st }}$ century market in primary and secondary education. The skills are listed in its publication entitled New Vision for Education: Unlocking the Potential of Technology (WEF, 2015: 3) where there are 16 skills grouped into 3 broad categories, namely:

1. Foundational literacies, how students apply core skills to perform daily tasks consisting of numerical literacy, scientific literacy, information literacy, communication and technology, financial literacy, and cultural and civic literacy.

2. Competencies, the students' ability to face complex challenges consisting of the ability to have critical thinking skills or problem-solving skills, creativity, communication, and collaboration.

3. Character qualities, how students face environmental changes which consist of curiosity, initiation, persistence, adaptation, leadership, and social and cultural aw areness.

Foundational literacy skills are basic skills that must exist before competencies and character qua lities skills. It is because by having good literacy, an individual is expected to be able to complete his or her basic daily tasks, especially in distinguishing various information. Therefore, it is very important for an individual to improve his or her literacy skills. Fadel and Trilling (2009: 66) state that at present the level of literacy and understanding to distinguish various information of the people must be increased. People need to understand and see information more analytically, critically, and reflectively.

Tests conducted by the Organization for Economic Cooperation and Development (OECD) in the Program for International Student Assessment (PISA). The 2009 PISA results show that the Indonesian students aged 15 years ranked 57th with a score of 396 (OECD average score of 493), while in 2012 showed that Indonesian students ranked $64^{\text {th }}$ with a score of 396 (OECD average score 496) (OECD, 2012). Those rankings were obtained from 65 countries participating in PISA 2009 and 2012. In addition, we can a lso see the results of the Progress International Reading Literacy (PIRLS) test in 2011 which evaluated the students'

1,2,3. Universitas Sebelas Maret, Surakarta, fahmibikeson@gmail.com, orcid.org/0000-0002-3013-6473 
reading skill of class IV. In the test, Indonesia ranked 45 of 48 countries taking the test with a score of 428 which was still below the average score of 500 (Mullis et al, 2012). From the data, it can be said that the practice of education carried out by schools in Indonesia has not achieved maximum results. As a learning organization, schools should strive hard to make the members in their environment to be literate so that they can form lifelong-learning personality.

Based on several problems that have been explained before, the Ministry of Education and Culture developed a literacy movement that involved all stakeholders in the field of education. This involvement is carried out thoroughly both at the central, provincial, regency/city, and education units. This literacy movement is contained in the Ministry Regulation number 23 of 2015 concerning with the growth of manners (Government of Indonesia, 2015). This ministry regulation initiated the emergence of the School Literacy Movement (GLS).

GLS is basically an activity that focuses on students' reading skill by involving all school members including the principal, teachers, students, parents of students and society around the school. School needs to ensure that the school's members have the same perception and understanding of the principles of reading activity (Pilgreen, 2000). This is done in order that the school ecosyst em can develop a conducive and literate academic atmosphere that can spur all elements in the school to have high enthusiasm for learning. The implementation of GLS itself is divided based on several levels of education, namely elementary schools, junior high schools, senior high schools, vocational high schools, and special education schools where each level of education has its own concept in accordance with the needs of the students at that level (Kemendikbud, 2016a:34).

At the senior high school level, GLS is expected to bring about a literate ecosystem in which this condition allows students to develop critical, creative, and social-empathy skills as well as knowledge affection. This is similar to what was conveyed by Widodo (2015:60) where literacy emphasizes students to be able to perform critical analysis, such as conducting interviews, observing the environment, writing reports, and observation. Students can carry out this activity by making a simple report and then presenting it in front of the class. From this kind of activity, hopefully, the students' interest in reading and writing can grow. The literacy activities which are funny for the students can realize active participation without being forced. When students enjoy literacy activities, it is hoped that students will be interested in conducting literacy activities independently. In addition, GLS is also expected to support the High Order Thinking Skills (HOTS) of students like critical thinking skills and crative thinking skills (Kemendikbud, 2016a: 28). This ability is needed by students to compensate for the National Examination (UN) questions which recently began to be developed using the HOTS approach where to do it the students need broad insight. To gain broad insight, the students are required to improve their literacy skills. It is GLS that appears to perfect the learning process so that the students have a broader insight.

Deli Serdang regency welcomed warmly the GLS program by launching the Deli Serdang Literacy Movement program. According to the head of education service of Deli Serdang regency, generally, the society's literacy skills have begun to improve. The improvement of the society's literacy skills can be seen from the start of many literacy activities in the society, such as the grow th of various reading houses and literacy villages in several areas of Deli Serdang regency as well as the existence of a reading circle program. In addition, the government of Deli Serdang regency has provided two mobile library cars that are man aged by the library and archive service of Deli Serdang regency. 


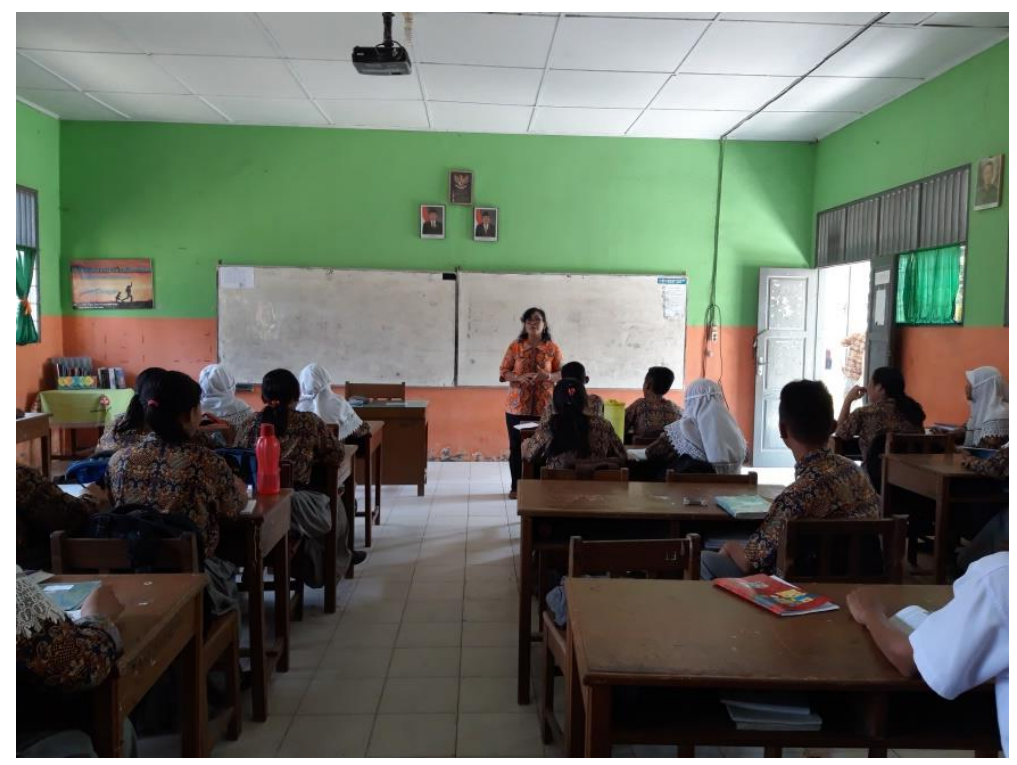

Picture 1. 15-minute reading activity guided by the teacher in SMAN 1 Lubuk Pakam.

Deli Serdang regency has also prepared its schools to implement the GLS program. As for the high school level, schools that have implemented the GLS program are State Senior High School 1 and 2 of Lubuk Pakam. Based on the results of the preliminary study, 15 minutes of reading activities at those schools have already begun at the beginning of the learning process. In addition, the education service of Deli Serdang regency has a series of programs as well (clean, neat, cool, shady) and child-friendly school program and family education. Those aforementioned programs are none other than to provide a comfortable environment for students to develop their literacy skills.

With the presence of GLS, it is expected that the students are more literate and have good creativity and critical thinking skills. This hope will not occur without the support of various parties such as teachers, librarian, staffs, and various elements of society to maintain the school ecosystem as an academic environment. In addition, parents must also be able to position themselves as motivators for their children to be more active in reading activities so that the GLS program can be maximized (Kemendikbud, 2016b: 14).

The problem regarding GLS looks interesting because the recent research has not discussed yet the recommendations for developing the GLS model. The existing research only focuses on the formal implementation of GLS activities in the schools where they conducted research. Therefore, the researcher is interested in finding new recommendations to improve and/or enhance the GLS program in schools, especially at the senior high school level in Deli Serdang regency.

\section{METHOD}

To answer the problem in this research, the researcher used qualitative research method conducted in two State Senior High School (SMAN) in Deli Serdang regency, namely SMAN 1 and SMAN 2 Lubuk Pakam which have implemented the GLS program. To carry out this research, the researcher took care of the research permit from Sebelas Maret University which was then given to the related schools. The sources of data in this research are words and actions, written data sources and statistics obtained from the field. To retrieve the data in the field, the researcher used field observation technique, interviews, and document analysis. The informants in this research consisted of 2 principals, 5 teachers, 3 librarians, and 10 students who were chosen randomly. In addition, the researcher also interviewed the chair of literacy initiator unit of Deli Serdang regency, the head of education service of Deli Serdang regency, and the secretary of library and archive service of the Deli Serdang regency. 
Tabel 1. List of Informan

\begin{tabular}{|c|c|c|c|}
\hline No. & Name of Informan & Position & School \\
\hline 1. & Drs. R. S, M.Si. & Headmaster & SMAN 1 Lubuk Pakam \\
\hline 2. & S. S., S.Pd. & Economic teacher & SMAN 1 Lubuk Pakam \\
\hline 3. & Drs. B. S. & Economic teacher & SMAN 1 Lubuk Pakam \\
\hline 4. & S.H. R. S.Pd. & Economic teacher & SMAN 1 Lubuk Pakam \\
\hline 5. & A. S., S.Pd. & Librarians & SMAN 1 Lubuk Pakam \\
\hline 6. & N. L., S.Pd. & Librarians & SMAN 1 Lubuk Pakam \\
\hline 7. & W. F. A. I. & Student & SMAN 1 Lubuk Pakam \\
\hline 8. & M. A. & Student & SMAN 1 Lubuk Pakam \\
\hline 9. & H. R.M. & Student & SMAN 1 Lubuk Pakam \\
\hline 10. & R. P.S. & Student & SMAN 1 Lubuk Pakam \\
\hline 11. & S. G. S. & Student & SMAN 1 Lubuk Pakam \\
\hline 12. & Drs. A, M.Si. & Headmaster & SMAN 2 Lubuk Pakam \\
\hline 13. & H. P., S.Pd. & $\begin{array}{c}\text { Economic teacher and } \\
\text { Librarians }\end{array}$ & SMAN 2 Lubuk Pakam \\
\hline 14. & W.S., S.Pd. & Librarians & SMAN 2 Lubuk Pakam \\
\hline 15. & M, S.E. & Economic teacher & SMAN 2 Lubuk Pakam \\
\hline 16. & R.C. H. & Student & SMAN 2 Lubuk Pakam \\
\hline 17. & S. Y.Z. & Student & SMAN 2 Lubuk Pakam \\
\hline 18. & S. J. S. & Student & SMAN 2 Lubuk Pakam \\
\hline 19. & T.A. S. & Student & SMAN 2 Lubuk Pakam \\
\hline 20. & T.S. & Student & SMAN 2 Lubuk Pakam \\
\hline
\end{tabular}

To validate the data, the researcher used sources triangulation and methods triangulation. The sources triangulation is done by obtaining data from different sources namely the interviewees from related parties and direct observation on the implementation of GLS model at SMA level. The methods triangulation is done by collecting data using several methods namely interviews and direct observation on the classroom situation when learning and environmental conditions of SMAN 1 and SMAN 2 Lubuk Pakam. 


\section{RESULT, DISCUSSION, AND SUGGESTIONS}

School Literacy Movement (GLS) is a participatory effort that involves all parties related to the school. This effort is carried out so that the long-life literate individual will be realized throughout life. According to Beers (2009: 2), the school literacy movement must use the following principles in its implementation:

1. The process of developing literacy goes according to a predictable stage of development.

2. A good literacy program runs in balance.

3. The literacy program is integrated with the existing curriculum.

4. Reading and writing activities can be done any time and any where.

5. Literacy activities emphasize the importance of oral culture.

6. Literacy must be able to increase aw areness of diversity both inside and outside the classroom.

Some of these principles are used in the implementation of GLS to create literate students. In addition to developing the literacy skill of the students through GLS, a good strategy is needed. Therefore, Beers (in Kemendikbud, 2016: 12-13) presents several stages of effective strategies that can be used in the learning process at school:

1. Conditioning literacy-friendly physical environment. The physical environment needs to look friendly and conducive to the learning process. This conditioning can be in a variety of $w$ ays, such as displaying the students' works at all school areas that are replaced regularly so that all students have the opportunity to show their works. Another way is to facilitate access to books and other reading materials through reading corners in classrooms, offices, and other areas at school.

2. Seeking a social and affective environment as a literate model of communication and interaction. The social and affective environment is built through a communication and interaction model conducted by all school members. The interaction can be done by awarding the students' achievements both academically and non-academically during flag ceremonies every week. In addition, literacy is expected to color all activities at school during the learning year. These activities can be realized in various forms of events such as book fairs, poster competitions, storytelling, and so on. The principal is also expected to play an active role in driving literacy by building collaborative cultures between teachers and education personnel. Thus, every school member can be involved in accordance with their respective fields. The creation of a good social and affective environment also involves the role of parents as volunteers. Parental involvement is needed to strengthen the school commitment in developing literacy culture.

3. Striving for school as a literate academic environment. The physical, social, and affective environment are closely related to the academic environment when it comes to school. School should provide enough time allocation in the learning process for literacy learning. One of them is to run reading activities for 15 minutes before the lesson begins. In addition, to develop the skills of teachers and staffs, the school needs to give them opportunity to participate in training programs to improve their understanding of the GLS program.

These three strategies are very important in the development of GLS because with a good strategy it will strengthen the existence of GLS itself in school. But again, the three strategies are only the basic concepts given. Each school can implement the strategy by adjusting it to the conditions and situations of the school.

For this reason, the GLS indicators are prepared so that each school can conduct self-evaluation to measure the achievement of the implementation of the GLS program in the school. The following are indicators of GLS achievement in school according to Kemendikbud (2016: 14):

1. There is a 15-minutes reading activity (reading silently or reading aloud) which is done every day regularly.

2. 15-minutes reading activity is done at least for a period of 1 semester.

3. Students have a daily reading journal.

4. Teachers, principals, and/or education personnel have become models in the 15-minutes reading activity by participating in reading during the activity. 
5. There is a library, reading corner in the classroom, and a comfortable reading area with non-lesson collection books.

6. There are reading campaign posters in the school environment.

7. There is rich text material in the class.

8. Clean, healthy, and rich-in-text Environment as well as the existence of posters about the habit of living clean, healthy, and beautiful.

9. School seeks to involve the society in developing GLS activities.

10. The principal and his staffs are committed to implement and support GLS.

Based on the results of interviews and observations conducted at SMAN 1 and SMAN 2 Lubuk Pakam, these two schools have run the GLS program. 15-minutes reading activity before the teaching and learning process begins is routinely carried out. Some strengths and weaknesses or obstacles are then revealed in relation to the implementation of the GLS program in both schools. The following is the explanation of the current conditions of the implementation of the GLS program in both schools.

\section{State Senior High School 1 Lubuk Pakam}

For SMAN 1 Lubuk Pakam, the implementation of the GLS program is considered good. The 15minutes reading activity before the teaching and learning process begins has been running for 2 years. Teachers are considered to be able to become reading role models during the 15-minutes reading activity. The books that the students read are non-learning books such as novels, regional stories, and biographies. The books are stored at the reading corner in the classroom. In a ddition, there are also various ty pes of textrich posters in the class such as the names of class cleaners, names of the students according to their seats, and learning-support posters. For the condition of the school environment, it looks comfortable and clean as there are enough trees to refresh the school. In almost every tree, there is also the name of the tree and its Latin name that allows the students to know directly about the tree. In each trash can, there is a label that distinguishes between the recyclable waste and the unrecyclable waste. In addition, the school also holds various literacy activities in collaboration with various parties such as book bazaar, poetry reading and writing competitions, short-story-making competitions, and the Deli Serdang mobile library car which is scheduled to visit the school each month.

How ever, there are several weaknesses in the implementation of the GLS program at SMAN 1 Lubuk Pakam. The first weakness in implementing GLS at SMAN 1 Lubuk Pakam is the 15 -minutes reading activity combined with the first lesson. The time allotment that should be used by the teacher to convey the lesson is taken 15 minutes to function as a reading activity. This makes it difficult for the teacher who has the first lesson every day to share learning time with 15 minutes of reading activity. The teacher must readjust the stages of teaching as well as the lesson plan he or she has made. The second weakness is the reading books used for 15-minutes reading activity are charged from the students themselves. This is considered to add to the burden of the students' costs to go to school. In addition, the absence of more visiting hours to the library makes the library quiet. Library visiting hours are only scheduled for breaks of as much as $2 \times 15$ minutes per day. This clearly makes the role of the library very minimal in improving the students' literacy.

\section{State Senior High School 2 Lubuk Pakam}

For SMAN 2 Lubuk Pakam, the implementation of GLS is also considered good. The 15-minutes reading activity before teaching and learning process begins has been running for 2 years. The 15 -minutes reading activity is carried out before the first lesson begins by accelerating the students' entry schedule to 07:15 WIB. This activity is guided by the teacher teaching at the first hour in the class. The teacher is able to be a reading role model during the 15 -minutes reading activity. The books that the students read are nonlearning books such as novels, regional stories, and biographies. Each classroom has a r eading corner so that the books used in the 15-minutes reading activity can be stored in the classroom. In addition, there are also various types of text-rich posters in the class such as the names of class cleaners, the names of the students according to their seats, and the learning-support posters. For the condition of the school environment, it looks comfortable and clean as there are trees that are quite crow ded to support learning in the school. In almost every plant, there is also a name label that allows the students to know directly about the plants. There are also some small huts and under-tree seating at SMAN 2 Lubuk Pakam that the students can use to 
discuss. In every trash can, there is a label that distinguishes between the recyclable waste and the unrecyclable waste. In addition, the school collaborates with various publics to hold various literacy activities such as book bazaar, poetry reading and writing competitions, short-story-making competitions, and book-making for the students' best works as a form of appreciation.

How ever, there are several obstacles that occur in the implementation of the GLS program at SMAN 2 Lubuk Pakam. The first obstacle is that there are some students who are late to go to school. As a result of the delay, the students cannot participate in 15-minutes reading activity before the teaching and learning process. The second obstacle is that the reading books used during the 15 -minutes reading activity are charged from the students themselves. This is considered to add to the burden of the students' costs. In addition, the absence of more visiting hours to the library makes the library quiet. Library visiting hours are only scheduled at the break times of $2 \times 15$ minutes per day. This clearly makes the role of the library very minimal in improving the students' literacy.

\section{Discussion about the Implementation of GLS at SMA Level in Deli Serdang Regency}

From the results of observations and interviews at two schools that have implemented the GLS program, it can be said that the implementation of the GLS program in both schools has been going well. Both schools only need further refinements to develop GLS activities in their schools. The development can be done by finding solutions to any obstacles that occur during the implementation of GLS in both schools. The following are 3 obstacles that occur during the implementation of the GLS program at SMAN 1 and SMAN 2 Lubuk Pakam:

1. At SMAN 1 Lubuk Pakam in particular, the 15-minutes reading activity carried out at the beginning of the learning disrupts the teaching and learning process.

2. The students who are late often do not attend the 15 -minutes reading activity.

3. The supporting-reading books for 15-minutes reading activity are still burdened to the students.

4. The library visiting hours are still minimal at both schools.

The first obstacle that occurred at SMAN 1 Lubuk Pakam was theimplementation of 15 -minute reading activities carried out at the beginning of learning to disrupt the teaching and learning process. The absence of special time given for the implementation of 15 -minute reading activities before learning makes learning effectiveness disrupted. The lesson time that should be used for subjects for 45 minutes, reduced to 30 minutes to be used in the program 15 minutes of reading before learning. Schools need to find solutions so that there is no reduction in teaching and learning time due to additional progra ms. But there is a solution that can be done by SMAN 1 Lubuk Pakam to overcome this. Schools can use management conducted by SMAN 2 Lubuk pakam. SMAN 2 Lubuk Pakam overcame the problem by speeding up the students' school entry schedule to $07.15 \mathrm{WIB}$, followed by carrying out 15 -minute reading activities. Another solution for schools is that the school stays in on schedule, but backs up all the lesson schedules as much as 15 minutes for 15 minutes reading. This was considered effective in overcoming the problem of adjusting the time for 15 -minute reading activities with the first subject. That way the teacher does not need to change the plan of the learning program so that the learning process can go according to what was previously planned.

Regarding the second obstacle, the students' delay can be minimized by having consultation with the students and their parents. This requires the role of the teacher of guidance and counseling (BK) to provide understanding to the students about the importance of 15 -minutes reading activity before the teaching and learning process begins. Furthermore, the teacher of guidance and counseling can work with the students' parents to control and minimize the students' delay to come to school. This is considered effective because the students can be aw are of their own interests in terms of learning so that the students' desire to not come late to school will grow. This is supported by a study conducted by Ökten (2016: 22) shows that family participation in education has a positive impact on child academic achievement. In addition, the students can be controlled from two sides, namely from parents and teachers at school. Parents can monitor the students' departure from home and the teachers can monitor the arrival time of the students from the school. In that way, it is expected that the number of the students who usually come late will decrease. 
Regarding the third obstacle, the books for 15-minutes reading activity which are still burdened to the students can be minimized by cooperating with various parties outside the school to help add to the books collection at schools. Some recommended parties are: (1) the school committee, (2) book publishers, and (3) the library and archive service of Deli Serdang regency. The school committee as an organization of parents' association is the public party closest to the school. It is expected that the school committee can help the school in holding books in the form of book donations or other things. The second public is the book publishers that can help with the procurement of books to schools directly. The third public is the library and archive service of Deli Serdang regency that can assist the school in the provision of supporting books for 15-minutes reading activity through the routine scheduling of mobile library car. It is necessary to have cooperation in borrowing books between the school and the library of the regency so that the students no longer have to bring reading books to the school by themselves.

Regarding the last problem which is visiting hours to the school library, the schools can overcome this problem by making a schedule for a class visit to the school library every week. This program, according to the head of the literacy initiator unit of Deli Serdang regency, Mr. Suryadi, has ever held at State Junior High School 1 Tanjung Morawa. This activity is in the form of a scheduling class reading visit to the school library every week. According to him, this activity can help enliven and make the school library feel more alive. With this library visit, the students can improve their literacy skill by reading library collection books. The school library can also provide e-Books facilities to support student literacy. Based on research conducted by Santoso (2018: 77), the use of e-Books is more effective than using printed books. Although using e-Books makes library visitors not visible in the field, at least the use of e-Books can provide the widest opportunity for students and other school residents to be able to read.

At the end, I would like to say that my research is only limited to one district of Deli Serdang, Indonesia. Therefore to find out thoroughly about the implementation of GLS in Indonesia, research is needed with a population covering a wider area. This is needed so that we can better understand the various problems that exist in the field and how to overcome those problems. Thus the results of my research, hopefully can be useful for me and the readers.

\section{REFERENCES}

Beers, C. S., Beers, J. W., and Smith, J. O. (2009). A principal's guide to literacy instruction. New York: Guilford Press.

Government of Indonesia (2015). Peraturan Menteri Pendidikan dan Kebudayaan Republik Indonesia Nomor 23 Tahun 2015 Tentang Budi Pekerti. Jakarta: Indonesian government secretariat.

Kemendikbud. (2016a). Desain Induk Gerakan Literasi Sekolah. Jakarta: Direktorat Jenderal Pendidikan Dasar dan Menengah Kementerian Pendidikan dan Kebudayaan.

Kemendikbud. (2016b). Panduan Gerakan Literasi Sekolah di Sekolah Menengah Atas. Jakarta: Direktorat Jenderal Pendidikan Dasar dan Menengah Kementerian Pendidikan dan Kebudayaan.

Mullis, I. V. S., Martin, M. O., Foy, P., and Drucker, K.T. (2012). PIRLS 2011 international results in reading. Boston: TIMSS \& PIRLS International Study Center and International Association for the Evaluation of Educational Achievement (IEA).

OECD (2014). PISA 2012 results in focus. Programme for international student assessment, 1-44. Retrieved September 15, 2018, from https://ww w.oecd.org/pisa/key findings/pisa-2012-results-overview.pdf

Ökten, P. (2016). Parental academic support in education. International Journal of Educational Research Review, $1(2), 19-24$.

Pilgreen, J. L. (2000). The SSR handbook: How to organize and manage a sustained silent reading program. Portsmouth, NH: Heinemann Boynton/Cook Publishers. 
Sihaloho,F.A.S., Martono,T. \& Daerobi,A. (2019). The implementation of school literacy movement at the senior high school.Interna tional Journal of Educational Research Review,4(1),88-96.

Santoso, T. N. B., Sisw andari, \&Sawiji, H. (2018). The effetiveness of ebook versus printed books in the rural schools in Indonesia at the modern learning era. International Journal of Educational Research Review, 3 (4), 77-84.

Sugiyono. (2017). Metode Penelitian Kebijakan: Pendekatan Kuantitatif, Kualitatif, Kombinasi, RED dan Penelitian Evaluasi. Bandung: Alfabeta.

Trilling, Bernie, \& Fadel, C. (2009). 21 st century skills, learning for life in our times. San Fancisco: Jossey-Bass, A Wiley Imprint.

Widodo, Slamet et al. (2015). Membangun Kelas Literat Berbasis Pendidikan Lingkungan Hidup Untuk Melatihkan Kemampuan Literasi Siswa di Sekolah Dasar. Prosiding Seminar Nasional Pendidikan. Sidoarjo: Universitas Muhammadiyah Sidoarjo. 60-73.

World Economic Forum. (2015). New Vision for Education: Unlocking the Potential of Technology. Retrieved September 17, 2018, from

http://www3.weforum.org/docs/WEFUSA_NewVisionforEducation_Report2015.pdf 